\title{
KUALITAS DAN KEBERHASILAN LULUSAN PRODI IAN FIS UNP DALAM MENDAPATKAN PEKERJAAN
}

\author{
Syamsir \\ Prodi Ilmu Administrasi Negara (IAN), Fakultas Ilmu Sosial, Universitas Negeri Padang \\ syamsirsaili@yahoo.com \\ Heni Candra Gustina \\ Prodi Ilmu Administrasi Negara (IAN), Fakultas Ilmu Sosial, Universitas Negeri Padang \\ nidraleona@yahoo.com
}

\begin{abstract}
This study aims to describe the success of Prodi IAN FIS UNP graduates in getting a job and to identify the factors determining the success of the graduates in finding employment. This research was conducted through quantitative and qualitative approaches. Data collected through questionnaires, interviews, and documentation on several private and government agencies in the province of West Sumatra where the alumni of Prodi IAN work. To obtain quantitative data the researchers used a technique of proportional sampling area through the tracer study. As for the qualitative data, the informant has been determined purposively. Qualitative data were analyzed through interactive models of analysis. While quantitative data were analyzed through descriptive statistical analysis in the form of frequency, percentage, and mean. The results of this study, among others, indicate that the sustainability of a study program depends not only on the ability of managers to manage the institution, but should also consider the needs of other stakeholders interested in the study program that is students, alumni, and the workforce.
\end{abstract}

Keywords: Successful, alumni, job and career

\section{Pendahuluan}

Program Studi Ilmu Administrasi Negara Fakultas Ilmu Sosial Univer-sitas Negeri Padang (Prodi IAN FIS UNP) mempunyai visi yang jelas untuk menjadi program studi yang handal dan berdaya saing tinggi sebagai pusat pengembangan sumber daya manusia yang berkualitas di bidang Ilmu Administrasi Negara. Harapan ke depan profil lulusan yang dihasilkan adalah lulusan yang memiliki kemampuan: (1) memanfaatkan teknologi informasi dalam mendesain dan mengelola organisasi sektor publik; (2) mengimplementasikan kebijakan publik; (3) mengelola pelayanan dan partisipasi publik; (4) memformulasikan alternatif penyelesaian masalah prosedural terkait dengan efektivitas dan efisiensi organisasi dan manajemen sektor publik; (5) merumuskan dan mengkomunikasikan alternatif solusi yang berada di luar kewenangannya kepada pimpinannya; (6) menyusun telaah staf dalam proses pembuatan keputusan serta melaksanakan tupoksi secara efektif dan efisien dengan menggunakan informasi dan kemampuan analisis yang dimilikinya; serta (7) mengelola sektor publik 
untuk mewujudkan nilai-nilai publik yang berlandaskan efisiensi, efektivitas, berkeadilan, dan demokrasi baik secara individual maupun tim ${ }^{1}$.

Sehubungan dengan itu maka output yang diharapkan dari para lulusan atau alumni Prodi IAN FIS UNP termanifestasi dalam wujud tenaga administrator publik atau manajer tingkat pertama (lower manager); birokrat pada tingkat operasional; analis kebijakan yang mampu memberi masukan dalam pembuatan keputusan strategis; pengelola kegiatan lapangan di sektor publik; serta memiliki kemampuan menyesuaikan diri dengan perkembangan kehidupan masyarakat lokal, nasional dan global ${ }^{2}$.

Di sisi lain keberhasilan para lulusan dalam mendapatkan pekerjaan sangat ditentukan oleh banyak faktor, baik eksternal maupun internal. Sementara itu, dalam rangka membentuk kompetensi lulusan yang berkualitas dan mempersiapkan lulusan yang siap bersaing dalam memperoleh pekerjaan tersebut maka salah satu prasyaratnya adalah menyusun kurikulum berbasis kom-petensi.

Dengan mengacu pada data mahasiswa Prodi IAN FIS UNP Tahun 2013, lulusan dari Prodi IAN tiap tahunnya rata-rata berjumlah 42 orang. Jumlah keluaran yang relatif cukup besar ini diharapkan secara keseluruhan bisa diserap oleh dunia kerja. Menurut Ario Wicaksono ${ }^{3}$, agar kapasitas dan kapabilitas yang dimi-liki mahasiswa memenuhi kriteria yang dibutuhkan dunia kerja maka diperlukan lulusan yang handal yang mampu menciptakan dan memelihara keadaan serta memiliki kerja keras, disiplin tinggi, dan selalu berorentasi terhadap perubahan sebagai sistem nilai yang mengikat pola-pola kelakuan organisasi dan masyarakatnya.

Dalam konteks ini, maka hakekat Ilmu Administrasi Negara/ Publik sebagai ilmu praksis akan selalu memperoleh visinya dari praksis Ilmu Administrasi Negara/ Publik, dan dari apa yang terjadi dalam realitas sosial. Dengan demikian profesi Ilmu Administrasi Negara/Publik adalah profesi yang terus-menerus berkembang karena praksis ilmu ini terus menerus terjadi dan unik bagi setiap individu dan masyarakat di dalam situasi dan waktu yang berbeda.

Berdasarkan perkembangan tersebut, maka Henrikus Triwibawanto Cedeona ${ }^{4}$ mengemukakan empat hal yang harus diperhatikan sehubungan dengan profil lulusan Ilmu Administrasi Negara/Publik terhadap kebutuhan lapangan kerja, antara lain: (1) memiliki kepribadian yang matang dan berkembang, (2) memiliki penguasaan ilmu yang kuat, khususnya Ilmu Administrsi Negara/Publik, (3) memiliki kemampuan dan keterampilan dalam membangkitkan minat warga belajar/peserta didik kepada ilmu pengetahuan dan teknologi, dan (4) mengembangkan profesi keilmuan secara berkesinambungan.

\footnotetext{
${ }^{1}$ Fakultas Ilmu Sosial UNP. 2012. Buku Panduan Akademik FIS UNP. Padang: FIS UNP.

${ }^{2}$ Ibid

${ }^{3}$ Ario Wicaksono. 2009. "Pendidikan Sebagai Langkah Pertama Upaya Reposisi Administrasi Negara di Indonesia". Makalah dalam Konferensi Administrasi Negara (KAN) ke 2 di Universitas Airlangga Surabaya, tanggal 8-9 Mei 2009.

${ }^{4}$ Hendrikus Tribawanto Gedeona. 2009. "Revitalisasi Kurikulum Administrasi Publik di Abad 21".Makalah dalam Konferensi Administrasi Negara (KAN) ke 2 di Universitas Airlangga Surabaya, tanggal 8-9 Mei 2009.
} 
Hasil tracer study Prodi IAN FIS UNP tahun $2010^{5}$ menunjukkan bahwa daya serap alumni IAN dalam dunia kerja masih rendah. Akhirnya, cukup banyak para alumni Prodi IAN juga menjadi kelompok pengangguran putus asa (discourage unemployment) yaitu pengangguran sudah bertahun-tahun mencari kerja tanpa hasil karena faktor demand for labor dan supply for labor yang makin tidak seimbang. Ketidakseimbangan itu terjadinya karena lebih besarnya penawaran ketimbang permintaan hampir di seluruh instansi pemerintah/BUMN/ BUMD/sektor industri/dunia usaha.

Dari fenomena di atas terlihat bahwa terdapat ketimpangan antara jumlah kesempatan kerja dengan angkatan kerja yang ada. Tingginya tingkat pengangguran yang dialami oleh para alumni perguruan tinggi menandakan para sarjana masih menjadi problem dan penambah beban berat angkatan kerja. Masalah ini memerlukan suatu kajian, terutama yang berkaitan dengan keberhasilan para lulusan prodi IAN UNP dalam mendapatkan pekerjaan, lamanya waktu tunggu lulusan memperoleh pekerjaan, faktor-faktor yang menjadi penentu para lulusan dalam mendapatkan pekerjaan, dan kendala yang dihadapi lulusan dalam memperoleh pekerjaan. Sehubungan dengan fenomena ini penulis telah mengadakan tracer study pada tahun 2014 untuk mengetahui sejauhmana kualitas dan keberhasilan lulusan Prodi IAN FIS UNP dalam mendapatkan pekerjaan.

Berdasarkan fenomena yang digambarkan dalam latar belakang masalah di atas maka persoalan yang ingin diketahui menalui penelitian ini antara lain: 1) Bagaimanakah gambaran keberhasilan lulusan Prodi IAN FIS UNP dalam mendapatkan pekerjaan pada berbagai instansi pemerintahan dan swasta? 2) Faktor-faktor apakah yang menjadi penentu keberhasilan para lulusan dalam mendapatkan pekerjaan pada berbagai instansi pemerintahan dan swasta? 3) Kendala-kendala apakah yang dihadapi lulusan Prodi IAN dalam memperoleh pekerjaan? dan 4) Bagaimanakah gambaran waktu tunggu lulusan Prodi IAN dalam memperoleh pekerjaan?

Hasil penelitian ini diharapkan bermanfaat untuk: (1) Mengukur dan melacak keberadaan lulusan dan kinerja lulusan sehingga dapat diperoleh indikator yang jelas tentang jumlah, profil kerja masa mendatang, dan relevansi kurikulum dengan dunia kerja; (2) Mempersiapkan kurikulum dan tingkat kemampuan lulusan yang sesuai dengan kebutuhan tenaga kerja (link and match) agar profil lulusan yang dihasilkan dapat terserap oleh dunia kerja yang lebih beragam dan dapat beradaptasi dengan dunia kerja.

\section{Tinjauan Kepustakaan}

Dengan memperhatikan dan mempertimbangkan beberapa tuntutan perubahan lingkungan, yakni perubahan paradigma (paradigm shift) dalam Ilmu Administrasi Negara Abad 21, tantangan globalisasi, kegagalan dalam pengelolaan pemerintahan, dan perubahan kebijakan pendidikan nasional yang dilakukan, secara langsung maupun tidak langsung pasti berpengaruh pada fokus

\footnotetext{
${ }^{5}$ Tim Prodi IAN FIS UNP. 2010. Laporan Tracer Study Prodi IAN. Padang: Prodi IAN.
} 
Ilmu Administrasi Negara itu sendiri. Pergeseran tersebut, suka atau tidak suka, senang atau tidak senang, mengharuskan Perguruan Tinggi yang memiliki program studi Ilmu Administrasi Negara untuk melakukan pembaharuan dalam kelembagaannya, baik itu menyangkut visi, misi, dan tujuan program studi; kurikulum (kompetensi) yang dikembangkan; proses pembelajaran untuk mencapai kompetensi yang diharapkan; pendidik dan tenaga kependidikan; serta sarana dan pasarana umum maupun penunjang proses pembelajaran.

Perubahan-perubahan yang ter-jadi ini tentu saja akan membawa perubahan dalam institusi pendidikan di Indonesia pada umumnya, dan secara khusus dalam tubuh Perguruan Tinggi Akademik maupun Kedinasan yang memiliki Prodi Ilmu Admi-nistrasi Negara. Hal tersebut tidak dapat dihindari karena tuntutan pasar lokal, nasional maupun internasional menghendaki adanya kualitas lulusan dari Prodi Ilmu Administrasi Negara yang baik dan kompetitif. Hal itu berarti berkaitan dengan kompetensi lulusan.

Untuk membentuk kompetensi lulusan yang berkualitas maka langkah yang harus dilakukan antara lain adalah menyusun kurikulum yang berbasis kompetensi. Adapun kompetensi yang dibangun adalah kompetensi yang dapat berkompetisi. Benyamin S, Bloom ${ }^{6}$ menyarankan perlu adanya tiga aspek utama berikut yang dijadikan acuan dalam rangka menyusun kurikulum pembelajaran, yaitu 1) aspek kognitif (cognitive aspect), 2) aspek afektif (affective aspect), dan 3) aspek psikomotorik (psychomotoric aspect).

Dari gagasan tersebut bisa dipahami bahwa kurikulum yang ideal yang dapat membentuk kompetensi lulusan, secara ringkas harus mencakup tiga dimensi utama, yaitu pengetahuan (ilmu dari disiplin yang dipelajari), sikap (perilaku yang baik dalam menerapkan ilmu dan berinteraksi dengan lingkungan), dan keterampilan (berkaitan dengan keahlian untuk mengaplikasikan teori).

Dimensi pengetahuan, keterampilan, dan sikap tersebut boleh dikatakan menyerupai apa yang diharapkan oleh pemerintah terhadap kurikulum pendidikan nasional kita, termasuk dalam kurikulum disiplin Ilmu Administrasi Negara. Menurut Sistem Pendidikan Nasional (UU No. 20/2003, pasal 36 ayat 3) ${ }^{7}$ dan Peraturan Pemerintah tentang Standar Nasional Pendidikan (PP No.19/2005, pasal 25 ayat 4 dan pasal 26 ayat 4$)^{8}$, yang dimaksudkan dengan kompetensi adalah mecakup akhlak mulia, memiliki pengetahuan, keterampilan, kemandirian dan sikap untuk menemukan, mengembangkan, serta menerapkan ilmu, teknologi dan seni yang bermanfaat bagi kemanusiaan.

Idealisasi yang diharapkan ini harus menjadi komitmen dari seluruh Perguruan Tinggi Akademik dan Perguruan Tinggi Kedinasan yang menekuni bidang Ilmu Administrasi Negara untuk diwujudkan. Pertanyaannya adalah bagaimana bentuk pembaharuan kurikulum, aksentuasi kurikulum Ilmu Administrasi Negara pada pendidikan Akademik, Profesi, dan Vokasi?

Kerangka Kualifikasi Nasional Indonesia (KKNI) sebagai peruwudan jati diri sistem pembangunan SDM di Indonesia dalam kerangka penjenjangan

\footnotetext{
${ }^{6}$ Dalam Hendrikus Tribawanto Gedeona. 2009. Op cit.

${ }^{7}$ Undang-Undang Nomor 20 Tahun 2003 tentang Sistem Pendidikan Nasional.

${ }^{8}$ Peraturan Pemerintah Nomor 19 Tahun 2005 tentang Standar Nasional Pendidikan.
} 
kualifikasi kompetensi dapat menyandingkan, menyetarakan, dan mengintekrasikan antara bidang pendidikan dan bidang pelatihan kerjaserta pengalaman kerja dalam rangka pemberian pengakuan kompetensi kerja sesuai dengan struktur pekerjaan di berbagai sektor. KKNI merupakan perwujudan mutu dan jati diri Bangsa Indonesia terkait dengan sistem pendidikan dan pelatihan nasional dimiliki Indonesia. Dalam hal ini evaluasi kurikulum perlu dilakukan melalui kebijakan universitas dan program studi, dengan menggunakan analisis SWOT melalui tracer study, serta masukan dari asosiasi dan stakeholders.

Meskipun demikian, apa yang menjadi state of the art of public administration science tetap menjadi jiwa dari kurikulum yang dibuat oleh Prodi Administrasi Negara/Publik di perguruan tinggi akademik maupun di perguruan tinggi kedinasan. Dengan perkataan lain kurikulum tidak pernah lepas dari ranah Ilmu Administrasi Negara/Publik. Hal-hal yang menjadi ruh dan ruang lingkup dari disiplin ilmu, tetap harus diakomodasikan dalam kurikulum, dengan berbagai inovasi di dalamnya ${ }^{9}$. Demikian juga halnya dengan penetapan mata kuliah inti nasional pada program studi Ilmu Administrasi Negara/Publik jenjang S1oleh Asosiasi Ilmu Administrasi Negara/Publik Indonesia (IAPA), seperti: (1) Teori organisasi; (2) Asas-asas manajemen; (3) Birokrasi; (4) Kebijakan publik; (5) MSDM sektor publik; (6) Kepemimpinan; (7) Metode penelitian; (8) Etika administrasi publik; (9) Sistem informasi manajemen; (10) Pengambilan keputusan; (11) Sistem administrasi negara; (12) Pengantar ilmu administrasi negara; (13) Hukum administrasi negara; (14) Pelayanan publik; (15) Administrasi pembangunan (Keputusan Ketua IAPA Nomor 004/KA.IAPA/ Kep/KP/ 2011). Sehingga mata kuliah yang menjadi ciri khas atau identitas dari Ilmu Administrasi Negara/Publik selalu saja sama dan harus ada antara perguruan tinggi akademik dan perguruan tinggi kedinasan yang memiliki Prodi Ilmu Administrasi Negara/Publik, meskipun dalam perundang-undangan telah diatur bahwa perguruan tinggi memiliki otonomi untuk menentukan kerangka dasar dan struktur kurikulum yang dikembang-kan dengan mengacu pada standar nasional pendidikan.

Sebagai disiplin ilmu, layaknya entitas sistem terbuka lain, Ilmu Administrasi Negara/Publik mengalami perkembangan substanstif melalui dan dalam keterbukaan serta interaksinya dengan lingkungan. Bahkan pergeseran paradigmatik sepanjang sejarah administrasi publik dapat dipandang sebagai sebuah dinamika konstruktif ${ }^{10}$. Dengan demikian aksentuasi kurikulum administrasi negara/publik semestinya berkembang sesuai dengan semangat zaman. Administrasi negara/publik modern yang berkembang saat ini, baik di tingkat teori maupun praksis, dibangun dengan berlandaskan pada jaringan-jaringan vertikal dan horizontal dari berbagai tipe organisasi publik, yang terdiri atas lembaga pemerintah (government), lembaga non-pemerintah (NGOs), dan semipemerintah (quasi-governmental organizations), baik yang bersifat profitoriented, non-profit oriented, maupun organisasi yang bersifat sukarela (voluntary

\footnotetext{
${ }^{9}$ Shafritz, J.M \& E.W. Russel. 1997. Introducing Public Administration. New york: AddisoWesley Educational Publishers Inc.

${ }^{10}$ Pius Suratman kartasasmita. 2006. Bringing The Public Back In, Revitalisasi Konsep Publik dalam Pemikiran dan Praktek Administrasi Publik di Indonesia. Yogyakarta: Graha Ilmu.
} 
organizations). Nilai atau jiwa utama administrasi negara/publik modern secara umum berusaha untuk mencakup pemahaman utama tentang komitmen publik, dan secara khusus berusaha memberi tanggapan (responses) terhadap kepentingan masing-masing individu dan kelompok warga negara. Bisa disimpulkan bahwa aksentuasi dalam administrasi negara/publik modern berkembang dari spektrum yang sangat sederhana hingga spektrum yang luas dan kompleks sesuai dengan perkem-bangan dan tuntutan organisasi publik.

\section{Metode Penelitian}

Penelitian ini termasuk jenis penelitian evaluatif kualitatif-kuantitatif dan bersifat deskriptif. Pendekatan kuantitatif diperkuat dengan pendekatan kualitatif (naturalistic). Oleh karena itu dalam penelitian ini digunakan metode survei dengan penggunaan pendekatan kualitatif guna mencoba memperoleh gambaran yang lebih mendalam serta pemahaman yang holistik berdasarkan situasi yang wajar (natural setting) dari objek dan subjek kasus yang diteliti dimana peneliti sendiri bertindak sebagai instrumen utama untuk memperoleh data langsung dari tangan pertama (first hand). Disamping itu data juga akan diperoleh melalui angket (kuesioner) yang disebarkan kepada para responden dalam mengidentifikasi dan menganalisis jawaban responden yang diperoleh melalui angket (questionnaire) dengan menggunakan analisis statistik dalam bentuk frekuensi, persentase, dan uji rata-rata (mean).

Populasi dalam penelitian ini adalah seluruh alumni (lulusan) prodi IAN UNP yang telah bekerja pada berbagai instansi pemerintah dan swasta. Berdasarkan populasi penelitian dan sesuai pula dengan permasalahan dan tujuan penelitian ini, maka penentuan sampel dalam penelitian ini, terutama untuk pengumpulan data kuantitatif, dilakukan dengan menggunakan teknik area sampling secara proporsional melalui tracer study. Disamping itu, untuk menghindari bias dalam pengambilan kesimpulan penelitian, juga dilakukan wawancara secara mendalam dengan beberapa informan, antara lain para pimpinan yang ada dalam lingkungan instansi yang bersangkutan, yang ditentukan secara purposive.

Pengolahan dan analisis data kuantitatif dalam penelitian ini dilakukan dengan menggunakan analisis statistik deskriptif dalam bentuk frekuensi, persentase, dan uji rata-rata (mean). Sedangkan analisis data kualitatif dalam penelitian ini dilakukan dengan menggunakan teknik interactive model of analysis melalui tahap reduksi data, display data, tafsiran data, dan pengambilan kesimpulan. Analisis kualitatif model interaktif dilakukan terus menerus dan berkelanjutan selama penelitian berlangsung

\section{Hasil Penelitian dan Pembahasan}

\section{Temuan Umum}

Dengan melihat kompetensi lulusan di tempat kerja, peneliti telah melakukan studi pelacakan (tracer study) terhadap para lulusan prodi IAN untuk semua angkatan (tamatan 2009 sampai tamatan 2014) yang diambil sampelnya secara area sampling dan proporsional. Selain itu juga dilakukan sistem penelusuran lulusan melalui 
berbagai cara, di antaranya adalah melalui: (1) penyebaran angket melalui situs jejaring sosial; (2) bincang-bincang dengan para alumni yang datang berkunjung ke kampus FIS UNP; (3) melalui pertemuan langsung dengan alumni;serta (4) komunikasi melalui surat dan telepon.

Dari hasil studi pelacakan tersebut diperoleh informasi bahwa lulusan Prodi IAN secara umum diakui kemampuan profesionalnya di dalam melaksanakan tugastugas yang diberikan, dan memiliki kepribadian yang terintegrasi. Pada umumnya alumni bekerja pada instansi pemerintahan, BUMN, BUMD, dan Swasta. Dari 400an orang alumni sampai pertengahan tahun 2014, diperkirakan sekitar lebih dari 100 orang alumni diantaranya sudah bekerja pada Satuan Kerja Pemerintah Daerah Kabupaten/Kota di Sumatera Barat, pada Kementerian Pendayagunaan Aparatur Negara dan Reformasi Birokrasi, dan Kementerian Keuangan Republik Indonesia, sedangkan yang lainnya bekerja pada BUMN/BUMD, dan ada 21 orang alumni yang melanjutkan studinya pada jenjang lebih tinggi program S2 (Magister) dan 12 di antaranya ter-identifikasi telah meyelesaikan pro-gram S2 nya, baik di dalam maupun luar negeri.

Meskipun banyak alumni Prodi IAN yang diakui kemampuannya dan berhasil di dunia kerja, namun bukan berarti bahwa semua lulusan Prodi IAN sudah memperlihatkan kompetensi sebagaimana yang diharapkan; terutama sekali para alumni yang baru tamat dan baru mulai bekerja. Kompetensi yang masih dirasa kurang terutama berkaitan dengan kompetensi berbahasa Inggris. Dari hasil pelacakan, untuk aspek ini, sebagian pengguna masih menyatakan bahwa kemampuan alumni PSIAN pada kriteria belum baik. Harapan Prodi ke depan adalah bahwa semua kompetensi yang diperlukan alumni di dunia kerja, sekurangkurangnya bisa dikuasai dengan baik. Di samping itu, masa tunggu lulusan untuk memperoleh pekerjaan perlu dipertahankan dan kalau dapat lebih diperpendek lagi.

Untuk dapat melihat lebih jelas kondisi alumni berdasarkan tracer study yang dilakukan dari Juli sampai November 2014 yang lalu, dengan total alumni yang terjaring sebanyak 72 orang alumni, dapat dilihat pada beberapa tabel dan uraian berikut ini.

\section{Keberhasilan Lulusan Prodi IAN FIS UNP dalam Mendapatkan Pekerjaan}

Keberhasilan lulusan Prodi IAN FIS UNP dalam mendapatkan pekerjaan pada penelitian ini antara lain dilihat dari keberhasilan alumni (lulusan) mendapatkan pekerjaan mereka pada berbagai instansi pemerintahan dan swasta, penempatan alumni dalam pekerjaan, dan cara alumni mendapatkan pekerjaan. Untuk melihat kondisi dan profil lulusan (alumni) berdasarkan bidang atau instansi pekerjaan alumni dapat dilihat pada Tabel 1 di bawah ini. 
Tabel 1. Bidang Pekerjaan Alumni

\begin{tabular}{lcccccccc}
\hline \multirow{2}{*}{ Bidang Pekerjaan } & \multicolumn{9}{c}{ Tahun Lulus } & \multicolumn{3}{c}{ TOTAL } & \% \\
\cline { 2 - 9 } & $2008 /$ & $2009 /$ & $2010 /$ & $2011 /$ & $2012 /$ & $2013 /$ \\
\\
\cline { 2 - 9 } & 2009 & 2010 & 2011 & 2012 & 2013 & 2014 & \\
Pemerintahan & 1 & 17 & 3 & 4 & - & 1 & 26 & $\mathbf{3 6 , 1}$ \\
BUMN & - & 5 & 5 & 2 & - & - & 12 & $\mathbf{1 6 , 7}$ \\
BUMD & - & 1 & 2 & 1 & - & - & 4 & $\mathbf{5 , 6}$ \\
Swasta & - & 11 & 6 & 3 & 4 & 3 & 27 & $\mathbf{3 7 , 5}$ \\
Wiraswasta/ usaha & - & 2 & - & - & - & - & 2 & $\mathbf{2 , 8}$ \\
Organisasi Internasional & - & - & 1 & - & - & - & 1 & $\mathbf{1 , 4}$ \\
\hline \multicolumn{1}{c}{ Total } & $\mathbf{1}$ & $\mathbf{3 6}$ & $\mathbf{1 7}$ & $\mathbf{9}$ & $\mathbf{4}$ & $\mathbf{4}$ & $\mathbf{7 2}$ & $\mathbf{1 0 0}$ \\
\hline
\end{tabular}

Berdasarkan Tabel 1 di atas dapat diketahui bahwa kebanyakan alumni PSIAN yang lulus antara tahun 2009-2014 bekerja pada sektor atau bidang pemerintahan (sekitar 36,1\%) dan sektor atau bidang swasta (sekitar 37,5\%). Sedangkan mereka yang bekerja di bidang atau sektor BUMN juga cukup besar, yaitu sekitar 16,7\%. Sementara alumni yang bekerja di sektor BUMD atau berwiraswasta sangat kecil persen-tasenya, yaitu masing-masingnya sekitar 5,6 \% dan 2,8\%. Disamping itu ada pula $1(1,4 \%)$ orang alumni yang bekerja pada organisasi internasional.

Banyaknya jumlah alumni lulusan 2009/2010 yang bekerja di insitusi pemerintahan ditengarai karena mereka memiliki kesempatan untuk mengikuti beberapa kali rekruitmen/tes CPNS terutama CPNS Daerah (CPNSD) yang lebih berorientasi putra daerah. Disamping itu, pada tahun 2009/2010 alokasi CPNS untuk bidang ilmu administrasi negara juga cukup banyak, sedangkan lulusan yang ada masih sedikit karena Prodi IAN UNP maupun UNAND baru berdiri di tahun 2004/2005 sehingga alumnus yang dihasilkan masih minim.

Cukup menarik melihat fakta bahwa 2,8\% atau 2 orang dari 72 alumni yang terdata bekerja secara mandiri atau berwiraswasta. Hal ini memperlihatkan adanya semangat kewirausahaan pada alumni meskipun bidang yang mereka tekuni merupakan warisan keluarga. Patut pula menjadi catatan bagi semua pihak bahwa lulusan ilmu administrasi negara tidak melulu harus terikat pada organisasi publlik namun dapat menjadi administrator mandiri yang membuka kesempatan kerja bagi pihak-pihak lain.

Selanjutnya keberhasilan alumni atau lulusan Prodi IAN dalam mendapatkan pekerjaan juga dapat dilihat dari penempatan pekerjaan alumni pada instansi tempat mereka bekerja. Untuk melihat kondisi dan profil lulusan (alumni) berdasarkan penempatan pekerjaan alumni dapat dilihat pada Tabel 2 di bawah ini. 
Tabel 2. Penempatan (Sektor) Pekerjaan Alumni di Tempat Kerja

\begin{tabular}{|c|c|c|c|c|c|c|c|c|}
\hline \multirow[b]{2}{*}{ Sektor Pekerjaan } & \multicolumn{6}{|c|}{ Tahun Lulus } & \multirow[b]{2}{*}{ TOTAL } & \multirow[b]{2}{*}{$\%$} \\
\hline & $\begin{array}{l}2008 / \\
2009\end{array}$ & $\begin{array}{l}2009 / \\
2010\end{array}$ & $\begin{array}{l}2010 / \\
2011\end{array}$ & $\begin{array}{l}2011 / \\
2012\end{array}$ & $\begin{array}{l}2012 / \\
2013\end{array}$ & $\begin{array}{l}2013 / \\
2014\end{array}$ & & \\
\hline Pelayanan & 1 & 19 & 9 & 5 & 1 & - & 35 & 48,6 \\
\hline Organisasi & - & 1 & - & - & - & - & 1 & 1,4 \\
\hline Manajemen & - & 2 & 1 & 1 & - & 2 & 6 & 8,3 \\
\hline Kebijakan & - & 3 & 1 & 1 & - & & 5 & 6,9 \\
\hline Pendidikan & - & 5 & 2 & 1 & - & 1 & 9 & 12,5 \\
\hline Industri & - & 1 & - & - & - & - & 1 & 1,4 \\
\hline Perdagangan & - & 2 & - & - & - & - & 2 & 2,8 \\
\hline Keuangan/ Perbankan & - & 5 & 4 & - & 1 & - & 10 & 13,9 \\
\hline Penegakan hukum & - & - & - & - & - & - & - & - \\
\hline Media & - & 1 & - & - & - & - & 1 & 1,4 \\
\hline Pengadaan brg \& jasa & - & - & - & - & - & - & - & - \\
\hline Lainnya & - & - & - & - & 2 & - & 2 & 2,8 \\
\hline Total & 1 & 39 & 17 & 8 & 4 & 3 & 72 & 100 \\
\hline
\end{tabular}

Berdasarkan Tabel 2 di atas dapat diketahui bahwa kebanyakan alumni PSIAN yang lulus antara tahun 2009 - 2014 ditempatkan dalam pekerja-annya pada bidang atau bagian pelayanan, yaitu sekitar 48,6\%. Disamping terlihat pula bahwa yang ditempatkan pada bidang keuangan atau perbankan juga cukup besar persentasenya, yaitu sekitar 13,9\% dan bidang pendidikan sekitar 12,5\%. Selebihnya penempatan alumni pada bidang pekerjaan lainnya sangat bervariasi, mulai dari bidang organisasi, manajemen, sampai pada bidang kebijakan, industri, perda-gangan, penegakan hukum, media, pengadaan barang dan jasa, dan lainlain, yang persentasenya sangat kecil seperti terlihat pada Tabel 2 di atas.

Sesuai dengan core function-nya sebagai public servant maka tak bisa dipungkiri bahwa penempatan posisi para alumni yang bekerja di organisasi publik lebih mengarah pada sektor pelayanan. Minimnya pengalaman dan belum lamanya masa kerja juga menjadi salah satu faktor yang menyebabkan para alumni masih berada di level lower management yang lebih banyak bersentuhan dengan aktivitas operasional organisasi.

Aspek selanjutnya yang digunakan untuk mengukur keberhasilan alumni dalam memperoleh pekerjaan adalah melalui cara mereka mendapatkan pekerjaan. Untuk melihat kondisi dan profil lulusan (alumni) berdasarkan cara mereka dalam mendapatkan pekerjaan dapat dilihat pada Tabel 3 di bawah ini.

Tabel 3. Cara Alumni Mendapatkan Pekerjaan

\begin{tabular}{lcrc}
\hline & Sumber Informasi & Jumlah & \% \\
\hline Kompetisi & & 44 & 61,1 \\
Rekomendasi & 9 & 11,4 \\
$\begin{array}{l}\text { Ditempatkan } \\
\text { Diminta Pengguna }\end{array}$ & - & - \\
Mencari Sendiri & \multirow{2}{*}{ Jumlah } & 17 & 23,61 \\
& & 2 & 2,78 \\
\hline & & $\mathbf{7 2}$ & $\mathbf{1 0 0}$ \\
\hline
\end{tabular}


Dari Tabel 3 di atas dapat pula diketahui bahwa kebanyakan alumni Prodi IAN mendapatkan pekerjaan dengan berkompetisi (sekitar 61,1\%). Sementara mereka yang mendapatkan pekerjaan karena diminta oleh peng-guna juga cukup besar persentasenya, yaitu sekitar $23,61 \%$. Sedangkan mereka yang mendapatkan pekerjaan berdasarkan rekomendasi hanya sekitar 11,4\%, mendapatkan pekerjaan atau mencari sendiri sekitar 2,78\%, dan tidak ada di antara mereka yang mendapatkan pekerjaan dengan cara ditempatkan.

Ketika para alumni mengikuti tes untuk mengisi posisi tertentu di suatu instansi maka mayoritas dari mereka harus bersaing dengan calon-calon lain dengan latar belakang pendidikan yang sejenis. Ada alumni yang mampu melewati tahapan-tahapan awal dari tes pekerjaan tersebut namun tereliminasi di tahapan-tahapan akhir yang lebih banyak menuntut kapasitas non-akademik.

\section{Faktor-faktor Penentu Keberhasilan Mendapatkan Pekerjaan}

Faktor-faktor penentu keberhasilan para lulusan dalam mendapatkan pekerjaan pada berbagai instansi pemerintahan dan swasta dapat pula diperhatikan dalam Tabel 4 berikut ini.

\section{Tabel 4. Pendorong Kemudahan Mendapatkan Pekerjaan}

\begin{tabular}{|c|c|c|c|c|c|c|c|c|c|}
\hline \multirow{3}{*}{$\begin{array}{l}\text { Pendorong Kemudahan } \\
\text { Mendapatkan Pekerjaan }\end{array}$} & \multicolumn{7}{|c|}{ Tahun Lulus } & \multirow{3}{*}{ TOTAL } & \multirow{3}{*}{$\%$} \\
\hline & $2008 /$ & $2009 /$ & 2010 & 2011 & $2012 /$ & $2013 /$ & $2014 /$ & & \\
\hline & 2009 & 2010 & 2011 & 2012 & 2013 & 2014 & 2015 & & \\
\hline Kemampuan yang dimiliki & 1 & 5 & 5 & 2 & 4 & 1 & - & 18 & 25,0 \\
\hline Ketersediaan formasi & 1 & 7 & 4 & & 2 & 3 & - & 17 & 23,6 \\
\hline Tingginya IPK yang dimiliki & 1 & 2 & - & - & 1 & 1 & - & 5 & 6,9 \\
\hline Latar belakang asal daerah & - & - & - & - & - & - & - & - & - \\
\hline Kemauan dan keuletan yg dimiliki & 1 & 4 & 6 & 3 & 2 & 1 & - & 17 & 23,6 \\
\hline Tidak memilih jenis dan lokasi & 1 & 2 & 3 & 1 & 2 & 3 & - & 12 & 16,7 \\
\hline $\begin{array}{l}\text { Memiliki relasi dengan instansi } \\
\text { tempat bekerja }\end{array}$ & - & - & 2 & - & - & - & - & 2 & 2,8 \\
\hline Kesuaian ilmu dengan formasi & - & 1 & - & - & - & - & - & 1 & 1,4 \\
\hline $\begin{array}{c}\text { Total } \\
\end{array}$ & 5 & 21 & 20 & 6 & 11 & 9 & - & 72 & 100 \\
\hline
\end{tabular}

Berdasarkan Tabel 4 di atas dapat diketahui bahwa kebanyakan alumni Prodi IAN yang lulus antara tahun 2009-2014 berhasil dalam memperoleh pekerjaan karena didorong oleh faktor kemampuan yang dimiliki (sekitar 25,0\%). Sementara faktor pendorong lainnya yang juga cukup besar mendorong keberhasilan alumni dalam mendapatkan pekerjaan adalah faktor ketersediaan formasi (sekitar 23,6\%) dan faktor kemauan dan keuletan yang dimiliki (23,6\%). Faktor "tidak memilih-milih pekerjaan" juga cukup besar persentasenya dalam mendorong alumni untuk memperoleh pekerjaan, sekitar $16,7 \%$. Sementara faktor tingginya IPK dan faktor relasi yang dimiliki dengan tempat kerja tidak begitu besar persentase pengaruhnya terhadap keberhasilan alumni dalam memperoleh pekerjaan, yaitu masing-masingnya hanya sebesar $6,9 \%$ dan $2,8 \%$ saja. Sedangkan kesesuaian ilmu dengan formasi yang tersedia hanya berkontribusi sekitar $1,4 \%$ saja menentukan keberhasilan mereka dalam memperoleh pekerjaan. 


\section{Kendala Lulusan Prodi IAN dalam Memperoleh Peluang Kerja}

Dalam memperoleh pekerjaan tentu saja ada kendala-kendala yang dihadapi, baik secara eksternal maupun internal Begitu juga dengan alumni Prodi IAN, kendalakendala yang dihadapi mereka juga cukup beragam dalam memperoleh peluang kerja. Kendala-kendala tersebut teridentifikasi sebagai berikut.

\section{Tabel 5. Kendala Alumni dalam Memperoleh Pekerjaan}

\begin{tabular}{|c|c|c|c|c|c|c|c|c|c|}
\hline \multirow[b]{2}{*}{ Kendala } & \multicolumn{7}{|c|}{ Tahun Lulus } & \multirow[b]{2}{*}{ TOTAL } & \multirow[t]{2}{*}{$\%$} \\
\hline & $\begin{array}{l}2008 / \\
2009\end{array}$ & $\begin{array}{c}2009 / \\
2010\end{array}$ & $\begin{array}{l}2010 / \\
2011\end{array}$ & $\begin{array}{l}2011 / \\
2012\end{array}$ & $\begin{array}{l}2012 / \\
2013\end{array}$ & $\begin{array}{l}2013 / \\
2014\end{array}$ & $\begin{array}{c}2014 / \\
2015\end{array}$ & & \\
\hline IPK rendah & - & - & - & - & - & - & - & - & - \\
\hline $\begin{array}{l}\text { Kurang Penguasaan bidang } \\
\text { ilmu }\end{array}$ & - & - & - & - & - & - & - & - & - \\
\hline Kendala administratif & 1 & 1 & 1 & - & - & - & - & 3 & 4,2 \\
\hline $\begin{array}{l}\text { Keterampilan yang } \\
\text { dimiliki rendah }\end{array}$ & 1 & - & 1 & - & - & - & - & 2 & 2,8 \\
\hline Persaingan ketat & - & 9 & 5 & 4 & 5 & 6 & - & 29 & 40,3 \\
\hline Tidak ada kendala & - & 10 & 15 & - & 12 & - & - & 37 & 51,4 \\
\hline Budaya kerja kurang baik & - & - & - & - & - & 1 & - & 1 & 1,4 \\
\hline Total & 2 & 20 & 29 & 4 & 17 & 7 & & 72 & 100 \\
\hline
\end{tabular}

Berdasarkan gambaran Tabel 5 di atas teridentifikasi bahwa kendala terbesar yang dihadapi alumni (lulusan) dalam memperoleh pekerjaan adalah faktor persaingan yang ketat (yaitu sekitar 40,3\%). Meskipun demikian, kebanyakan mereka (sekitar $51,4 \%$ ) menyatakan bahwa mereka tidak menemui kendala yang berarti dalam memperoleh pekerjaan. Sementara sebahagian dari mereka menyatakan bahwa kendala mereka dalam mem-peroleh pekerjaan adalah karena kendala administratif, rendahnya keterampilan, dan budaya kerja yang kurang baik, namun persentasenya tidak begitu besar, masing-masingnya hanya sekitar 4,2\%, 2,8\%, dan $1,4 \%)$.

\section{Lama waktu tunggu lulusan Prodi IAN dalam memperoleh pekerjaan}

Untuk memperoleh gambaran tentang lama waktu tunggu lulusan Prodi IAN dalam memperoleh pekerjaan pertama dapat pula dilihat dalam Tabel 6 di bawah ini. 
Tabel 6. Profil Lulusan Berdasarkan Masa Tunggu Untuk Mendapatkan Pekerjaan Pertama

\begin{tabular}{|c|c|c|c|c|c|c|c|c|c|c|c|}
\hline \multirow{3}{*}{$\begin{array}{l}\text { Tahun } \\
\text { Lulus }\end{array}$} & \multicolumn{10}{|c|}{ Waktu Tunggu Untuk Mendapat Pekerjaan } & \multirow{3}{*}{$\begin{array}{c}\text { Total } \\
\text { Lulusan } \\
(\%)\end{array}$} \\
\hline & \multicolumn{2}{|c|}{$\begin{array}{c}\text { Sudah } \\
\text { Bekerja }\end{array}$} & \multicolumn{2}{|c|}{$<3$ bulan } & \multicolumn{2}{|c|}{$\begin{array}{c}3-6 \\
\text { bulan }\end{array}$} & \multicolumn{2}{|c|}{$\begin{array}{l}1-2 \\
\text { tahun } \\
\end{array}$} & \multicolumn{2}{|c|}{$\begin{array}{l}\text { Lebih dari } \\
2 \text { tahun }\end{array}$} & \\
\hline & $\mathrm{Jml}$ & $\%$ & Jml & $\%$ & Jml & $\%$ & $\mathrm{Jml}$ & $\%$ & $\mathrm{Jml}$ & $\%$ & \\
\hline $2009 / 2010$ & 5 & 27,8 & 14 & 50,0 & 14 & 60,8 & 1 & 33,3 & - & - & $34(47,2)$ \\
\hline 2010/2011 & 7 & 38,8 & 5 & 17,8 & 7 & 30,4 & - & - & - & - & $19(26,3)$ \\
\hline $2011 / 2012$ & 3 & 16,6 & 3 & 10,7 & 2 & 8,69 & 1 & 33,3 & - & - & $9(12,5)$ \\
\hline $2012 / 2013$ & 2 & 11,1 & 2 & 7,14 & - & - & 1 & 33,3 & - & - & $5(6,94)$ \\
\hline $2013 / 2014$ & 1 & 5,55 & 3 & 10,7 & - & - & - & - & - & - & $4(5,55)$ \\
\hline $2014 / 2015$ & - & - & 1 & 3,57 & - & - & - & - & - & - & - \\
\hline Total & 18 & 25,0 & 28 & 38,9 & 23 & 31,9 & 3 & 4,7 & - & - & 72 \\
\hline
\end{tabular}

Dari Tabel 6 di atas dapat dilihat bahwa rata-rata masa tunggu alumni (lulusan) PSIAN untuk memperoleh pekerjaan pertama cukup singkat. Sebagian besar diantara mereka (sekitar 70,8\%) menyatakan bahwa masa tunggu mereka kurang dari 6 bulan, bahkan 38,9\% di antara mereka mengaku bahwa masa tunggu mereka dalam memperoleh pekerjaan pertama adalah kurang dari 3 bulan. Disamping itu 25\% dari mereka mengaku sudah bekerja sebelum lulus dari studi. Sedangkan untuk rentang masa tunggu $1-2$ tahun persentase-nya sangat kecil, yaitu sekitar $4,7 \%$, dan tidak satupun dari mereka yang memiliki masa tunggu lebih dari 2 tahun.

Setelah lulus, sebagian alumni memilih bekerja di institusi swasta sembari menunggu lowongan CPNS yang tak dapat dipungkiri masih menjadi tujuan utama. Institusi swasta (perbankan dan lembaga pemmbiayaan kendaraan) yang semakin berkembang jumlahnya di Kota Padang dan sekitarnya tentu saja membutuhkan tenaga kerja yang lebih banyak dibanding lembaga pemerintahan. Tidak adanya kriteria spesifik yang diharapkan dari para fresh graduate membuat posisi ini menjadi incaran banyak alumni dari berbagai bidang studi. Hal ini tampaknya menjadi salah satu alasan mengapa para alumni PSIAN membutuhkan waktu yang relatif singkat untuk mendapatkan pekerjaan.

\section{Pembahasan}

Berdasarkan hasil studi pelacakan seperti yang telah disebutkan di atas terlihat bahwa bahwa lulusan Prodi IAN secara umum cukup diakui kemampuan profesionalnya di dalam melaksanakan tugas-tugas yang diberikan, dan memiliki kepribadian yang terintegrasi. Pada umumnya alumni bekerja pada instansi pemerintahan, BUMN, BUMD, dan Swasta. Sebagian besar dari alumni diantaranya sudah bekerja pada Satuan Kerja Pemerintah Daerah Kabupaten/Kota baik di Sumatera Barat maupun di luar Sumatera Barat seperti pada Kementerian Pendayagunaan Aparatur Negara dan Reformasi Birokrasi, dan Kementerian Keuangan Republik Indonesia, dan lain-lain. Sedangkan yang lainnya bekerja pada BUMN/ BUMD, dan ada beberapa orang di antara alumni yang melanjutkan 
studinya pada jenjang lebih tinggi program S2 (Magister) dan 3 di antaranya telah meyelesaikan program S2 nya, baik di dalam maupun luar negeri.

Namun demikian, walaupun banyak alumni Prodi IAN yang diakui kemampuannya dan berhasil di dunia kerja, namun bukan berarti bahwa semua lulusan PSIAN sudah memperlihatkan kompetensi sebagaimana yang diharapkan; terutama sekali para alumni yang baru tamat, dan baru mulai bekerja. Kompetensi lulusan yang dirasakan masih belum seperti yang diharapkan pengguna terutama kompetensi berbahasa asing, khususnya lagi bahasa Inggris. Dari hasil pelacakan, tergambar bahwa harapan alumni terhadap Prodi ke depan antara lain agar semua kompetensi yang diperlukan alumni di dunia kerja dapat dipenuhi di bangku perkuliahan melalui perbaikan proses pembelajaran dan pelengkapan sarana dan prasarana.

Begitu juga hasil wawancara dengan para pengguna lulusan antara lain menggambarkan bahwa kemam-puan alumni perlu ditunjang dengan dengan kemampuan bahasa Inggris dan keterampilan dalam menggunakan TI (Teknologi Informasi) dengan baik. Disamping itu, masa tunggu lulusan untuk memperoleh pekerjaan perlu dipertahankan dan kalau dapat lebih diperpendek lagi.

Untuk dapat memenuhi harapan-harapan tersebut ada beberapa komponen yang harus dibenahi berdasarkan masukan dari tracer study, antara lain:

1) Komponen sumber informasi pekerjaan. Pengelola Prodi IAN memiliki kesempatan besar untuk menjembatani kebutuhan antara penyedia lapangan kerja dengan pencari kerja. Pada dasarnya hubungan yang dimiliki antara Pengelola Prodi IAN dengan berbagai organisasi publik terutama yang telah memiliki kerjasama untuk program magang (internship) dapat ditindaklanjuti. Dengan demikian apabila institusi publik membutuhkan pekerja dengan kriteria yang dimiliki alumni Prodi IAN maka pengelola dapat merekomendasikannya. Kerjasama model ini tentu menghasilkan simbiosis mutual-isme bagi semua pihak.

2) Komponen harapan alumni ter-hadap lembaga. Para alumni merasakan pentingnya keseimbangan antara komponen skill, attitude, dan knowledge. Dengan demikian materi mata kuliah yang ada dalam kurikulum harus mengakomodasi unsur-unsur tersebut. Penting bagi pengelola Prodi IAN untuk menyediakan alokasi yang memadai untuk bidang keterampilan atau keahlian umum yang dibutuhkan dunia kerja. Dengan cara ini kesenjangan antara kebutuhan penyedia lapangan kerja dengan pencari kerja dapat terjembatani.

\section{Penutup}

Keberlangsungan sebuah program studi tidak hanya bergantung pada kemampuan pengelola untuk memanajemen institusinya namun perlu juga diperhatikan kebutuhan stake-holder lain yang berkepentingan terhadap program studi yakni maha-siswa, alumni, dan dunia kerja.

Mahasiswa memiliki kepen-tingan untuk memperoleh gambaran dan aplikasi yang jelas dari kurikulum yang disediakan program studi demi keberlanjutan pembelajaran dan ketersediaan lapangan pekerjaan bagi mereka kelak. Sedangkan alumni membutuhkan kompetensi yang seimbang antara skill, 
attitude, dan knowledge agar mampu bersaing dalam pasar kerja. Begitu pula dengan dunia kerja yang meng-harapkan para pekerja terdidik dan terlatih dengan kapasitas serta kapabilitas yang mampu mengantisipasi persaingan global.

Melalui tracer study pengelola Prodi Ilmu Administrasi Negara berupaya mengidentifikasi kebutuhan pasar kerja lewat kontribusi alumni dan masukan dari penyedia lapangan kerja. Dari hasil tersebut diperoleh beberapa profil seputar alumni Prodi IAN lulusan 2009/2010 hingga 2013/2014. Rerata alumni Prodi IAN bekerja di lembaga swasta sembari menunggu lowongan CPNS. Lembaga swasta memang menawarkan lebih banyak peluang kerja dibanding instansi pemerintah/BUMN/BUMD yang pola rekruitmennya relatif terjadwal dan terbatas. Kuantitas lembaga swasta yang terus bertumbuh di Sumatera Barat khususnya, dan besarnya kebutuhan pihak swasta terhadap tenaga kerja terutama fresh graduate membuat waktu tunggu para alumni untuk mendapatkan pekerjaan semakin pendek.

Dalam rangka menindaklanjuti hasil pengolahan data tracer study alumni PSIAN maka ada dua poin penting yang hendaknya menjadi agenda pengelola PSIAN dalam jangka pendek yakni:

1) Perlunya penyeimbangan porsi an-tara teori dan praktek administrasi negara dalam kurikulum perkuliahan;

2) Perlunya memperbanyak praktek lapangan dalam mata kuliah tertentu sehingga pemahaman mahasiswa/alumni lebih komplit dan mereka lebih siap untuk meng-hadapi dunia kerja mereka setelah mereka tamat dan bekerja;

3) Sehubungan dengan need assessment dari penyedia lapangan kerja/ pengguna jasa, maka peningkatan kemampuan Bahasa Inggris dan TI mahasiswa semasa kuliah baik lisan maupun tulisan perlu diakomodasi oleh pengelola Prodi IAN.

\section{DAFTAR KEPUSTAKAAN}

Ario Wicaksono. 2009. "Pendidikan Sebagai Langkah Pertama Upaya Reposisi Administrasi Negara di Indonesia". Makalah dalam Konferensi Administrasi Negara (KAN) ke 2 di Universitas Airlangga Surabaya, tanggal 8-9 Mei 2009.

Fakultas Ilmu Sosial UNP. 2012. Buku Panduan Akademik FIS UNP. Padang: FIS UNP.

Hendrikus Tribawanto Gedeona. 2009. "Revitalisasi Kurikulum Administrasi Publik di Abad 21".Makalah dalam Konferensi Administrasi Negara (KAN) ke 2 di Universitas Airlangga Surabaya, tanggal 8-9 Mei 2009.

Tim Prodi IAN FIS UNP. 2010. Laporan Tracer Study Prodi IAN. Padang: Prodi IAN.

Pius Suratman kartasasmita. 2006. Bringing The Public Back In, Revitalisasi Konsep Publik dalam Pemikiran dan Praktek Administrasi Publik di Indonesia. Yogyakarta: Graha Ilmu. 
Shafritz, J.M \& E.W. Russel. 1997. Introducing Public Administration. New York: Addison-Wesley Educational Publishers Inc.

Undang-Undang Nomor 20 Tahun 2003 tentang Sistem Pendidikan Nasional.

Peraturan Pemerintah Nomor 19 Tahun 2005 tentang Standar Nasional Pendidikan.

Peraturan Presiden Nomor 8 Tahun 2012 tentang Kerangka Kualifikasi Nasional Indonesia (KKNI). 